\title{
How Education Became Nobody's Business
}

\author{
BARRY MACDONALD \\ Centre for Applied Research in Education, University of East Anglia
}

ABSTRACT Political control has yielded a compulsory school curriculum of mindnumbing sterility, devoid of educational imagination or intelligence, and enforced by a crude technology. How did this come to be the outcome of a century of mass education, mass democracy, and social research? Where do educators and educational researchers go from here?

The last quarter of a century in this country has been marked by a seemingly inexorable concentration of civic power in the hands of central executive government, to an extent not previously seen in peacetime. Countervailing and mediating interest groups, such as local government, labour unions and professional associations, the judiciary, the universities, even the civil service and Parliament itself (as Scott has clearly demonstrated) have been seriously, some would say fatally, weakened. The process continues. Gagging clauses are increasingly inserted into the contracts of social service employees, a somewhat paranoid embellishment in view of the prudence generated by widespread job insecurity. Substantive democracy has been residualised to the franchise, provoking calls, mainly from those derided as the 'chattering classes', for a new Constitutional settlement. Such a scenario is, however, nowhere on the agenda of either government or opposition benches, whose disputes on such weighty matters are restricted to the pros and cons of a Freedom of Information Act and a revised composition of the Upper House. Curiously, and despite appearances to the contrary, they are as one on the issue of how schools can best contribute to an 'enterprise' economy. The answer, it would seem, is to drain them of all enterprise other than marketing. Meantime, with the reappearance of destitution on the streets and lanes of our urban and rural ghettoes, democracy looks more and more like the maintenance of power and privilege by other means. Was not 
mass education, now a century old, meant to change all that, and was not social science, now of similar age, supposed to supply the blueprint?

The Secretary of State for Education (and Employment) has assumed unprecedented powers. In schooling these powers have been used (and here I am spoiled for choice) to install a curriculum specification that might well have been borrowed from the Victoria and Albert museum. The details are too well known to readers of this journal to call for reiteration here, but I would point to the marginalisation of personal, social and anything remotely conducive to political education entailed in the specification and embodied in teacher accountability for its delivery. I might also mention the ethnocentric assimilationism that is assumed in the programme; this in a country where, in London alone, more than 80 tongues are spoken. The space for educative agency or even mediation is closing fast; payment by test results will be its death warrant.

Some will maintain that nothing has changed, that what Goodson (1988), following Bernstein, calls the deep structure of curriculum, differentiation linked to a social base' has merely been made more transparent. This is true as far as it goes. The traditional route to higher education has been maintained for those whose expectations, aspirations and stomach fit them for the climb: for the rest, basic skills plus the rudiments of patriotic history, parochial geography and socially sanitised science. But the 'plus ca change' conclusion is insufficient. What the Government has done, in dismissing the Schools Council for 'mediocre' performance, is to dismiss its mission. That was, in general terms, to prepare for the raising of the school leaving age by making the curriculum and pedagogy, particularly of the secondary school, more engaging and more relevant to the life of the average pupil. That involved a more liberal reinterpretation of subject matter, thematic integration of disciplines around human issues, more enquiry-based learning, and more child-centred approaches. It was not the conservatism of teachers that frustrated these efforts, but rather the conservatism of their own and their governing institutions.

What has been dismissed is the problem of pupil motivation. Flugel, writing in the $1930 \mathrm{~s}$, offers, from a psychoanalytic perspective, this distinction. "The older education, relying on coercion and the doctrine of formal training, and insisting on the performance of unpleasant tasks in order to cultivate the "will", usually held--implicitly if not explicitly--that it does not matter what a child is taught so long as he hates it. The newer education would rather take the view that only what arouses a child's interest can be satisfactorily and profitably taught ${ }^{3}$ (Flugel, 1933). As examples of the latter he points not to normal schools, but to re-educative institutions for juvenile offenders, such as Homer Lane's Little Commonwealth, from which those elements of 'hate and sadism' in the scholastic tradition had been expunged. Makes you think of our own, dear Home Secretary, doesn't it?

Teachers face a formidable problem of pupil resistance to a bread and water diet, and it is difficult to see how a more coercive regime than most of them aspire to can be avoided. Those who now queue up to buy the delivery vans of the effective schools movement will discover that the wrappings of the curriculum. 
cannot for long disguise the merchandise. Already the writing is on the wall, with headteachers complaining that temporary suspensions are insufficient to deal with recidivist recalcitrants. The Government has taken note and is now considering a proposal from Dearing that, for certain categories of pupil, the school leaving age be lowered to 14 . Such a prospect offers a curious inversion of the Home Secretary's attitude to sentencing. Pupils who misbehave will receive a 2 year remission. Now, there's a motivater for tomorrow's 'Mcjob' holders.

It is possible, of course, that the whole damn mess is meant to fail, as a prelude to privatisation, perhaps along the lines of those city administrations in the United States which have handed over the running of their school systems to private operators. Perhaps the far Right critics of curriculum control have underestimated the ingenuity of the executive. Although I'm not given to conspiracy theory, and would readily concede that long-term planning is not high on the list of political priorities, I must admit I was somewhat puzzled by the rather flustered and defensive reaction of the Secretary of State to the 'shocking' news that half the country's 11 year olds had turned in below standard performances in the national tests of attainment in English and mathematics. Didn't she know? After all, they were her tests, commissioned and custom built to her requirements. There is no independent standard. The first thing that a competent technologist of attainment tests asks of the customer is 'what percentage of the testees do you want to fail?'. Only on that basis can the technologist proceed with confidence to construct the tests and deliver the required result. Did the test people get it wrong? Was she really flustered, or does she have up her sleeve a more generous cut-off point next year for a pre-election performance boom, only to be followed by a slump? Testing is a dangerously flexible instrument when it falls under direct political control.

I prefer, marginally, a cock-up explanation of these results and reactions, a view reinforced by a response made by the Opposition spokesman during a radio phone-in programme following up the bad news. Throughout an otherwise smooth and confident denunciation of the Government's responsibility, he hesitated only once. That was when he was asked, Where do we get this standard from, then?'. There followed an atypical pause, at the end of which $\mathrm{Mr}$ Blunkett muttered something about 'comparison with other countries'. That might sound reasonable, were it not for the fact that for many years now the educational economists in the OECD have been tearing their hair out trying, and failing, to establish a valid basis for such international comparisons (see OECD, 1992, for a non-progress report). This difficulty, of course, does not inhibit our politicians, who increasingly invoke bogus international comparisons to bolster their arguments about a construct, 'standards', that neither they, nor the public, understands in terms of how it is now applied to the success or failure of schooling. In this context, buying yourself a psychometrist is like buying yourself an accountant. They can do amazing things for you, without breaking any rules.

Broadening the focus to consider the whole package, let us consider how the Government contrived to sell this pup to the public. In the first place, it 
helped considerably that New Labour, give or take a cavil here and there, bought it, thus confining fundamental opposition to the dispossessed, the so-called 'educational establishment', an imaginary Goliath of which our fearless Prime Minister, in the mantle of David, boldly declared he was unafraid. Now, apart from anything else, it is the duty of the Opposition to oppose, so that the public can make up its mind at least partially on the basis of alternative scenarios. In this case there was a massive dereliction of that duty. As far as education is concerned, the promised 'breath of fresh air' turned out to be almost entirely composed of air freshener. Labour continues to believe that education is about quantity.

In the second place, it helped that from the beginning of the period we are considering the public became aware of living in an economically failing society. In such circumstances schooling is invariably scapegoated. Throughout the period, successive governments relentlessly plugged deficit models of the schools, the teachers, the pupils and the workforce. During the Thatcher years a very special contempt was levelled at the $60 \mathrm{~s}$, a contempt so venomous at times that it is not enough simply to point to the fact that Labour was in office. It is tempting to add, following Flugel, that that was a decade in which hate and sadism plumbed unacceptably low levels, and some quite ordinary people danced rather than slept on the pavements. Ah, the sins of the fathers.

These attacks destabilised public opinion and professional confidence, distracted attention from contracting resources and paved the way for the legislation of the $80 \mathrm{~s}$. As the National Curriculum was unveiled, and with it the means of mobilising economic bias in the conception, delivery and control of schooling, the Government made its sales pitch directly to the public. The appeal was couched in simple, clear terms - it was an appeal to the public's 'common sense'. So it was 'common sense', in the name of equality of opportunity, to have a National Curriculum. The same for all, what could be fairer than that? And a familiar one, so parents could help kids with the homework. Targets, benchmarks and objective tests to keep kids and teachers up to the mark- 'common sense'. As the Government warmed to its theme, more 'common sense' made an appearance-segregation by ability, whole class teaching, larger classes. Sorry, delete that last one, there's only so much mileage in any slogan.

Now where, I ask myself, have we heard this before? Ah, yes. In 1986 the Reagan administration published a 65 page document (US Department of Education), entitled What Works: research about teaching and learning, which instantly became an unprecedented best seller in the field of education. It claimed to summarise a century of scholarship and empirical research in forty one findings of practical significance. It also claimed that these findings could be culled from the thoughts of the great educational thinkers of all time. In the preface to the document the President wrote of the 'renewed trust in common sense' emerging from the summary, which indeed argued that the findings were consistent with what experience and intuition would suggest. The reaction to the publication was instant. It was celebrated in the media and applauded by 
many leading educational researchers across the land, presumably in the hope that this vindication of the utility of their profession would release in the aftermath a flow of federal funds. Within a year Gene Glass published a masterly refutation of What Works, ridiculing its conservative selectivity, pointing to the many 'overlooked' studies that contradicted the findings, particularly the many researches that found in favour of open rather than traditional organisation of learning, collaborative rather than competitive learning and smaller classes (Glass, 1987). He also pointed to the ideological congruence of the document with established Reaganite policies, in particular its maintenance 'that the only needed reform in schooling is a change in the ethos of the school and classroom-ma change in the way teachers and parents think about and act towards children -not a change in the level of resources invested in education'. Noting successive cuts in the federal research budget for education during the Reagan years (other than for statistics), Glass ended his analysis by quoting Chester Finn, principal author of What Works and Assistant Secretary for Research and Improvement. In an interview some months after the publication, Finn declared that the restoration of the quantitative database for American education was now his highest priority, with 'new research' only the fourth.

So there we have it, two nations divided by a common language, united by common sense. Lucky really that common sense is confined to low cost propositions, isn't it? The future of educational research is at least at risk, in both countries, with downsizing a certainty. In the USA, even if we see What Works as a burial with honours as the feds respectfully withdraw (haven't you seen the movie?), the checks and balances in that country are so strong and so well resourced that tomorrow could easily be another day. Here, an ice-floe and a strong push have already put a premium on our foraging skills and a price on our survival. And there's no sign yet of a rescue party.

It has to be said that this wasn't in the plan. It wasn't in the plan that politicians could still, at this stage of the game, pick and mix from our knowledge store according to taste. What plan? Let me give you a hint by again crossing the Atlantic, to listen to a lament by a prominent American researcher, commenting on the decline of educational research and development as a feature of the policy landscape just a few years after What Works.

Research and Development advocates envisioned an eventual outpouring of new instructional processes and products that would make education less of an art and craft and more of a science. Schools, through the adoption of new scientifically developed techniques, were to be transformed into productive institutions contributing to a powerful national economy and capable of breaking the cycle of poverty. (Guthrie, 1990)

He concludes that after 25 years 'the inability of research to contribute a visible scientific basis for instruction has rendered schooling increasingly vulnerable to reform fads'. And, we might add, to political sequestration. 
Now you remember the plan. It was hatched in the 19 th century by the great encyclopaedic minds (Comte, Spencer, Durkheim and Weber) for implementation in the 20 th. It was called a science of society, a science that, as it matured, would assume a corresponding authority over social policy and social action. For Comte, sociology would become the 'queen' of science, while for Spencer all sciences would become as one. Narrowing the frame to late Victorian England (and wishing we'd had Weber rather than Spencer for inspiration), we find the cult of science at its height and, amidst the rampant greed of the new capitalists and the squalor of their casualties, hopes of a better world to come, a more just and more rationally ordered society. Mass education was under way, mass democracy around the corner.

How did we get from there to the end of this century, indeed the end of the millenium, these accomplishments being only remarkable for the fact that we, along with the termites and a few other species have survived and that the poor will pay for the fireworks from the National Lottery? Obviously I can't tell the whole story, only one bald summary with specific interests in mind. Looking back, we can see that what social research inherited from the Victorian reformists, in order to carry out the mission of justice through rationality, was a methodological poisoned chalice, what O'Connor (1957) called a 'Chinese box'. Some of us, who do fieldwork in the 'swamp of important human concerns' (Schon, 1987) are still struggling to escape, while others, as we have seen, are likely to press on. The poison, of course, was the notion (imperative' might be more accurate) that a science of mind and of social organisation, based on a model devised for prediction and control, would automatically serve the aims of individual and social emancipation. The view of science as a benevolent, even 'noble' activity, yielding technologies that enhanced the quality of life, was firmly established in the visionary mind. Why not harbour the same hopes by adopting the same methods, for a science of life?

For some this entailed a belief that the book of nature, material and human, would ultimately prove to be a single volume, written in mathematics. Physics was the ascendant paradigm, mechanism the buried treasure, mathematics the decoding procedure. The order of the established sciences was the order of their assumed numeracy, a rating scale bequeathed to their social progeny.

So what happened? Briefly, something like this. In the first place, capitalism won, just about everything. In the second place, Marx, Freud and Galton had more influence on our thinking than the founding fathers of sociology. In the third place, the book of nature was torn apart by specialisation and became a paper chase, pursued by what Ortega y Gasset referred to as the 'learned ignoramuses' who had replaced the encyclopaedic minds of the previous era (Ortega y Gassett, 1930). In the fourth place the public image of science changed, as the physical and biological sciences became industrialised, bureaucratised and militarised, caught 'helplessly' in the rising cost of their own technology. That image started with Rutherford in a Manchester cellar, commending his small group of students for their improvised adaptation of discarded tobacco tins to manufacture the apparatus of experimental physics 
(Andrade, 1965). It moved from there through Oppenheimer and the Manhattan Project to Star Wars, a conspiracy (yes, conspiracy) between Government, science and its associated industries to defraud a scientifically illiterate public of $\$ 30,000,000,000$. At the present time it is estimated that almost half the world's scientific/technological work force is engaged in the death industry ('defense' if you're squeamish, but most of it is exported). But now a new image has taken precedence, that of the bioengineer queueing up at the patent office to lodge a blueprint for a new life form. The icons of yesteryear (despite the efforts of Tomorrow's World) are today's fallen idols, perhaps tomorrow's 'condottieri' (see Nowotny, 1985). And nobody has the slightest idea what to do about it. The scientists (a few of them) call for more education, but we can't do much from an ice-floe.

What about the social sciences, rational control and all that? Well, really there's not much to say. Economics has done well in the corridors of power, despite an early warning from Albion Small, founder of the first graduate school of sociology in the world, in Chicago (Small, 1907). An admirer of Adam Smith, he noted the increasing divorce of economic reasoning from its roots in motal philosophy, castigated the 'new' economics as a 'grammar without language' and warned that the celibate social science was doomed to sterility. Maybe the message didn't cross the ocean but (pace Tawney, Keynes and Will Hutton in our own day) sterility certainly pays the bills, and those who staff the Government's think tanks don't appear to be short of testosterone.

As for sociology, well, slow to get started and reluctant to get metric is the story, at least in this country. A visiting American sociologist, as late as the mid-60s, was so shocked by the lack of mathematical competence in the professors she met, and this, she said indignantly, in the birth place of psychometrics and social survey, that she was moved to propose they attend a summer school in the States, so that they might, as she put it, understand the articles in the leading journals (Selvin, 1965). As for the slow start, for the first half of the century sociology was resisted by the conservative universities, as was psychology to a lesser extent. Philosophy and social anthropology were entrenched and unwilling to roll over. It wasn't until the welfare state got well underway that sociology flourished, and not until the late 60 s and early 70 s that it 'discovered' curriculum as a key to social and economic maintenance (Young, 1971). Not much since then. Whitry (1985) sees a need to 'retrieve the radical promise of a sociology of the curriculum', through oppositional politics on a broad front. Let us hope that the ever-expanding market for social survey can keep it in business until then.

Psychology is yet another story, and my last one. Unlike sociology, its utility was immediately grasped, or at least that part of it on which I have already focussed. In the context of the development of schooling as a sorting and selection process for a modemising society characterised by an expanding bureaucracy, the growth of the professions and the proliferation of specialised occupational skills, its success was assured. Central to that success was the quantitative, mathematical character of psycho-statistics, on which the mental 
testing movement was based. Mental testing, the most widely used social technology of the 20th century, went on to have a huge influence across the whole of society, not least upon the determination of life chances via the credentialling functions of educational provision. The story of its uses and abuses is well known (see for instance Karier, 1973). I would just point to its evolution as a technology increasingly detached both from its parent discipline and from its original moorings in educational values. Driven, by a combination of its internal logic and the conditions of its marketability, to pursue precision rather than span, it has in global terms become, despite or arguably because of its limitations, big business, both in the public and the private sector. Its values can be hidden, its stochastic processes are inaccessible to all but a few, but its products have the appearance of simplicity, transparency and fairness.

So, take away the psycho-statistic machinery and what have we got left? As educators, looking around for some authoritative support, from our own and related research, the answer must be 'not a lot'. Subjective assertion, argument, persuasion based on suggestive evidence. No more. During the 70 s and $80 \mathrm{~s}$ we discarded the disciplines and initiated a methodologically patchwork effort to build a new and holistic theory from the study of practice (the 'swamp' referred to earlier). We would claim both that it worked, that it was cumulative and that it served policy needs. But those were the needs of an open, dynamic system and a process of continuous change. Now we face a hostile state and a closed system, whose only acknowledged needs are for management and surveillance. The business of the schools is no longer a business we want to be in.

Even if we do so want, Government funding of educational research is now conditional upon disavowing ownership of its products and vowing silence with regard to their contents or how Government makes use of them. Invoking Rothschild's principle, never intended by him to be applied to social research, such knowledge has now been commodified and privatised for the discretionary use of the executive and its agents. There's been no fuss about this from our employers, the universities. There is room for us under the shroud of secrecy that already marks the incorporation of the ivory towers in the business of government and industry. The pressure to sell or be damned is something we are all acutely aware of in an increasingly competitive environment.

As for the future, there is one lesson. The Government divided and rules, we divided and lost. We must change that, as Whitty suggests. Perhaps we need a banner. I like this one, though the time line is a bit optimistic (it's from the USA) '... by the year 2000 we should be number one in the world in the percentage of eighteen year olds that are politically and socially involved. Far more important than our mathematics and our science scores is the involvement of the next generation in maintaining our democracy and helping those within it who need assistance-the young, the ill, the old, the retarded, the illiterate, the homeless and the hungry. Schools that cannot turn out politically active and socially helpful citizens, should be identified and their rates of failure announced in the newspapers' (Berliner, 1993).

$\mathrm{OK}, \mathrm{OK}$ it needs a bit of adjustment, but I like the last line, don't you? It 
does travel well, Actually, we need more, we need a curriculum for skepticism, a 'show me, don't tell me' curriculum. The 'learned ignoramuses' of a fragmented science are now creating a new, genetically engineered world with effects that are beyond their powers of prediction or control. If we cannot presently do much about the school curriculum, perhaps we should concentrate our educative effort more on a core curriculum for the $30 \%$ of the population now in our universities. Here follows the first topic- "To boldly go" is more than a syntactical error. Discuss'.

Correspondence: Barry MacDonald, Centre for applied Research in Education, University of East Anglia, Norwich NR4 7TJ, UK.

\section{REFERENCES}

ANDRADE, DA C. (1964) Rutherford and the Nature of the Atom (London, Hememann).

BeRLINER, D.C. (1993) Educational reform in an era of disinformation, Education Policy Analysis Archives, 1(2), pp. 1-43.

FLugel, J.C. (1933) A Hundred Years of Psychology (London, Duckworth).

GLASS, G.V. (1987) What works: politics and research, Educational Researcher, April, pp. 5 10.

Goodson, 1. (1987) School Subjects and Curriculum Change (Brighton, Falmer Press).

Gutrake, J.W. (1990) Education R \& D's lament, and what to do about it, Educational Researcher, March.

KARIER, C. et al. (1973) Roots of Crisis: American education in the twentieth century (Chicago, Rand McNatly).

Nowotny, H. (1985) Does it only need good mer to do good science, in: M. GrbBons \& B. WITTROCK (Eds) Science as a Commodity: threats to the open community of scholars (London, Longman).

O'Connor, D.J. (1957) The Philosophy of Education (London, Routledge and Kegan Paul).

OECD (1992) The OECD International Education Indicators, a Framework for Analysis (Paris, OECD).

ORTEGA Y GAsset, J. (1930) The Revolt of the Masses (New York, Signet Books, Edition, 1950). SCKON, D.E. (1987) Educating the Reflective Practitioner (London, Jossey Bass).

SELVIN, H.C (1965) Training for social research, the recent American experience, in: Penguin Survey of the Social Sciences 1965 (London, Penguin).

SMAII, A.W. (1907) Adam Smith and Modem Sociology (Chicago, University of Chicago Press). US DEPARTMENT OF EDUCATION (1986) What Works: research about teaching and learning (Washington, DC, Department of Education).

WhrTrT, G. (1985) Sociology asd School Knowledge (London, Methuen).

YounG, M.F.D. (Ed.) (1977) Knowledge and Control (London, Collier-MacMillan). 